\title{
A Legal Framework for Outer Space Activities in Malaysia
}

\author{
Tunku Intan Mainura
}

Faculty of Law, university teknologi Mara,40450 Shah Alam, Selangor, Malaysia

\section{Introduction}

One common similarity that Malaysia has between itself and the international space programme ${ }^{1}$ is the year 1957. For Malaysia it was the year of Independence ${ }^{2}$ and for the international space programme, the first satellite, Sputnik 1, was launched to outer space by the Soviet Union $(\mathrm{USSR})^{3}$. That was 56 years ago. Today outer space is familiar territory to states at large and Malaysia is one of the players in this arena ${ }^{4}$. Although it has been commented by some writers that Malaysia can be considered as new in space activities, since its first satellite was only launched into orbit in $1997^{5}$, nevertheless, it should be highlighted here that its space activities have grown very rapidly since then because in a time span of ten years, in 2007 it has sent its first astronaut to the International Space Station ${ }^{6}$.

Malaysia's space activities can be divided into three main programmes. They are the space science and technology programme, the astronaut programme

1 Gibson, R., 'The history of international space programmes', (2007) 23 (3) Space Policy 155.

${ }^{2}$ Mahathir, M., and Irwan, F., 'Malaysia's role in Asian regional cooperation: A look at foreign policy themes', (2007) 14 (2) Asia-Pacific Review 97.

3 Jackson, N. M., 'The military ascent into space: From playground to battleground - The new uncertain game in the Heavens', (2005) LII (3) Netherlands International Law Review 461.

${ }^{4}$ Brown, F., 'The changing face of space', (2007) 23 (2) Space Policy 69.

${ }^{5}$ Allaudin, M. F., Peter, N., Md Said, M. A. and Nor, K., 'Capacity building for the space sector: Microsatellite as a way forward. The example of the University of Sains Malaysia', (2005) 57 (2-8) Acta Astronautica 554.

${ }^{6}$ Luo, G., (ed.), 'Malaysian astronaut blasts into space', (2007) 3 (14) Asia-Pacific Space Outlook 8. and space education programme ${ }^{7}$. In order for Malaysia to ensure that its activities under the programme of space science and technology can be effectively undertaken, Malaysia has built space infrastructures, which includes the national observatory and remote sensing centres ${ }^{8}$. Activities under the space science and technology programme includes the satellite technology activities. Under this activity, Malaysia has participated in it by having six satellites in orbit. Nevertheless, these satellites were not launched from Malaysia's territory, as Malaysia does not have a launching facility 9 . They were all launched as payloads from other countries. For example, MeaSAT 1 and MeaSAT 2 which were the first Malaysian privately owned satellites were launched aboard an Ariane rocket in January and November 1996 respectively from Kourou, French Guiana ${ }^{10}$. TiungSAT which

7 Malaysia Space Agency's official web site, $<$ http://www.angkasa.gov.my/welcome/Menu/defau lt.php $>$.

${ }^{8}$ These national observatory and remote sensing centres have the purpose of supervising and monitoring space network frequencies and coordinating space networking, providing a platform for Malaysian scientists and international astronomers to do research on space science, and controlling and maintaining the satellite operations. Malaysia Space Agency's official web site, $<$ http://www.angkasa.gov.my/welcome/Menu/defau lt.php $>$.

${ }^{9}$ Since Malaysia actively participates in satellite activities, a proposal has been made by the Malaysian government to build its own rocketlaunching site in the near future. BBC Online, $<$ http://news.bbc.co.uk/1/hi/world/asiapacific/810057.stm>, 'Malaysia seeks place in space'. Reported on 28 June 2000.

10 The MeaSAT system is the first Malaysian privately owned satellite, operated by Binariang. The MeaSAT system provides the first direct-to- 
was launched in September 2000 and MeaSAT 3 which was launched in December 2006 were both launched from Baikanor, Kazakhstan ${ }^{11}$. RazakSAT which was launched in July 2009 was launched from Omelek Island in the Republic of the Marshal Islands ${ }^{12}$. As for the second type of programme available in Malaysia, that is the astronaut programme, on the 10 October 2007, Malaysia has witnessed the departure of its first astronaut, Sheikh Muszaphar Shukor Al Masree, to the International Space Station ${ }^{13}$. As for the third programme,

user (DTU) service in Malaysia, as well as general communications services in an area reaching from India to Hawaii and from Japan to East Australia. Both MeaSAT spacecraft were built by Hughes Space and Communications Company (HSC) in El Segundo, California. MEASAT Satellite Systems Sdn. Bhd.'s official web site, <http://www.measat.com.my/>.

11 TiungSAT 1 is Malaysia's first national micro satellite which was built by Astronautic Technology (M) Sdn Bhd (ATSB) and Surrey Satellite Technology Limited. The purposes of this satellite are earth observations, scientific Cosmic-Ray Energy Deposition Experiment (CEDEX) and simple communications applications. Amateur Satellite Organisation's official web page, <http://www.amsat.org/amsat/sats/n7hpr/tiungsat1.h tml>. As for MeaSAT 3 the information can be found at MEASAT Satellite Systems Sdn. Bhd.'s official web site, <http://www.measat.com.my/>.

12 RazakSAT is medium-sized aperture camera satellite, which was developed jointly by Astronautic Technology (M) Sdn Bhd (ATSB) and SaTReCi (SaTReCi Initiative Co Ltd) of Daejeon, Korea. RazakSAT functions include electro-optical earth observation, telecommunications and space science. The information for RazakSAT can be found at Amateur Satellite Organisation's official web

page,

<http://www.amsat.org/amsat/sats/n7hpr/tiungsat1.h tml $>$.

${ }^{13}$ Luo, G., (ed.), 'Malaysian astronaut blasts into space', (2007) 3 (14) Asia-Pacific Space Outlook 8. This astronaut programme however, has been criticised by some of the Malaysian public as unnecessary and a waste of public money. See 'Comments by Malaysian public about space programme of Malaysia', <http://www.malaysiakini.com/news/73524>, 'Is he an astronaut or space tourist?', reported 12 October 2007. In reply, Malaysia's government has stated that this astronaut programme does not utilise public funds as the financial burden of this namely the space education programme, Malaysia has activities to encourage the public to be interested in learning about space, by organizing many events suitable for the public, for example astronaut fashion design and drawing competitions, carnivals, planetarium shows, and a rocket launching technology challenge ${ }^{14}$.

programme is borne by the Russian government. This is due to the fact that this programme is a project that is the result of an offset agreement between Malaysia and Russia, when Malaysia purchased the Sukhoi-30MKM fighter jets from Russia. As such, under this agreement the Russian government is responsible for the cost of training and sending of two Malaysian astronauts to the International Space Station. See New Straits Times Online, $29 \quad$ September 2007, <http://www.nst.com.my/Current_News/NST/Sund ay/Focus/20070929194127/Article>. Malaysia's government also states that the Malaysian people and the country will gain benefits from this programme because the scientific research done in the International Space Station will contribute greatly in the fields of space medicine, aviation medicine, life science, environmental science and physics. See Malaysia Space Agency's official web site, http://www.angkasa.gov.my/

${ }^{14}$ Under the programme of space education, they include astronaut fashion design and drawing competitions, carnivals, planetarium shows, and a rocket launching technology challenge. See Malaysia Space Agency's official web site, http://www.angkasa.gov.my/. Space education is also being taught at schools and universities, whereby they include the teaching of space law in some universities in Malaysia. See Space Law Update, Volume 2, Issue 2, September 2005, United Nations Office of Outer Space Affairs official website,

<http://www.unoosa.org/oosa/en/SpaceLaw/spacela wupdate/index.html>. As regards to the space education programme, it should be mentioned that although the activities under the theme of space education do not require an actual legal framework, nevertheless the purpose of mentioning it here is for the purpose of acknowledging Malaysia's involvement in its space activities. The fact should also be highlighted here that the subject of space is relatively new for the general public of Malaysia because before the programme of space education was introduced by the Malaysian government, the public knew very little about space and its benefits. However, since the introduction of the space education programme, many Malaysians are now 
All these programmes and activities are lead by Malaysia's national space agency, known as ANGKASA, a cluster under the Ministry of Science, Technology and Innovation (MOSTI). ANGKASA was established in 2002 with the purpose of leading and observing the development of space science in Malaysia through three efforts, namely, providing leadership in the educational aspect and the research of space science, assisting the government in formulating and executing the National Space Policy and providing quality service to customers to help achieve the above-mentioned goals. In order for it to be effective, the management of ANGKASA is divided into four divisions. They are the Operations and Space System Division, the Technology Development \& Applications Division, the Space Science \& Education Division and the Administration \& Human Resource Division ${ }^{15}$. Whilst the Operations and Space System Division, and the Technology Development \& Applications Division are both based at the National Space Centre, the Space Science \& Education Division is based at the National Planetarium, and the Administration \& Human Resource Division is based at Putrajaya Headquarters $^{16}$. With the establishment of ANGKASA, it can be observed that there is in existence in Malaysia an institution that is responsible for managing and administering the

aware and alert about matters or activities concerning space. See Berita Harian Online's official web site,

<http://www.bharian.com.my/Current_News/BH/Sa turday/Sembang/20071229104545/Article/>,

'Interview with Professor Datuk Dr. Mazlan Othman, Director General of Malaysia National Space Agency', reported on 29 December 2007. Should also be highlighted here the fact that for the European countries, it has been suggested that in order for the benefits and potential of space activities to be understood clearly, space policy teaching should be introduced to students in the universities or even high school. This approach is considered important because it is very important to communicate the benefits that space activities have brought and as such the information can educate the society to further supporting the space activities. See Reibaldi, G. G., 'The importance of space policy teaching in communicating space activities to society', (2003) 53 (12) Acta Astronautica 997.

15 Malaysian Space Agency's official web site, http://www.angkasa.gov.my/

16 Malaysian Space Agency's official web site, http://www.angkasa.gov.my/ space activities of Malaysia. Furthermore it has also been commented that 'as ANGKASA also holds extensive consultations with other governmental agencies to ensure that there is maximum alignment of the national efforts in terms of education, capacity building, applications, technology acquisition and development, regulations and advancement of knowledge, the establishment of ANGKASA is seen to be the most crucial move for the Malaysian space program, ${ }^{, 17}$.

\section{Case Study}

Malaysian was chosen as the prime candidate for this study because it is a rapidly developing State entering the space race and as such may highlight issues of relevance for other developing states wishing to enter that same race. It was also chosen as a representative of states in the South East Asia region ${ }^{18}$. Although it may be asked why Malaysia was chosen since it is in the middle of developing its outer space legislation and the draft Bill is still subject to change, the explanation is that there are no other states in the South East Asia region that have national space legislation. Although other states in the region are also active in space-related activities, for example Indonesia which has up-todate launched 12 satellites ${ }^{19}$ and Thailand which has up-to-date launched 7 satellites ${ }^{20}$, nevertheless these states do not have national space legislation ${ }^{21}$. Therefore, since Malaysia has taken the forward step in drafting national space legislation, its draft legislation is the only available legislation that can be used as an example of national space legislation developed by a developing State in the South East Asia region.

The UK, USA, Japan and Australia were used as case study states. They were used for the purpose of

${ }^{17}$ Allaudin, M. F., Peter, N., Md Said, M. A. and Nor, K., 'Capacity building for the space sector: Microsatellite as a way forward. The example of the University of Sains Malaysia', (2005) 57 (2-8) Acta Astronautica 555.

${ }^{18}$ South East Asia consists of Burma (Myanmar), Cambodia, Laos, Thailand, Vietnam, Malaysia, $\underline{\text { Brunei, East Timor, Indonesia, the Philippines and }}$ Singapore. Found

〈http://en.wikipedia.org/wiki/Southeast_Asia〉.

19 See the UNOOSA web site at $<$ http://www.unoosa.org/oosa/search.do $>$.

20 See the UNOOSA web site at $<$ http://www.unoosa.org/oosa/search.do $>$.

21 See the UNOOSA web site at <.http://www.unoosa.org/oosaddb/browse_all.jsp?le vel1 $1=$ countries \&level $2=$ none $>$. 
learning from their experience, that is as illustrations of how international law could be implemented. As the purpose of this research was to find an ideal shape of a space legislative framework for Malaysia which can also be used by other states who have similar characteristic as Malaysia, i.e. a developing common law country who is an active participant in its space-related activities, the choice of the states whose legal framework is to be analysed is based on the relevancy of those states and their legislation to Malaysia. These have been chosen according to these five following criteria: firstly, whether they are active in space, secondly, treaty membership, thirdly, juridical background, fourthly, as exemplars of coherent or piecemeal approaches and fifthly, degree of collaborative activity. Applying these criteria the chosen states are the United Kingdom (UK), the United States of America (USA), Australia and Japan. Thus, although there are other neighbouring states whose legal framework could be analysed due to their active participation in space-related activities, for example India and China, the fact that they do not have specific legal frameworks pertaining to their space-related activities makes them unsuitable candidates for the purpose of this research.

In particular, the UK is chosen from all other spaceactive European countries due to the historical linkage that it has with the Malaysian legal system where, Sections 3 and 5 of Malaysia's Civil Law Act 1956 allows for the application of English common law, equity rules and statutes in Malaysian civil cases where no specific Malaysian laws have been made. Furthermore, the UK is chosen because of its involvement in the European Space Agency's programme and because the materials are in a language the researcher is proficient in. The reason for selecting the USA is mainly due to the length and complexity of its space-related activities and legal framework. In other words, the choice of the USA is justifiable because of the degree of its involvement in space activities. Additionally, unlike the UK which has a single legal framework, the USA's legal framework consists of many chapters, which provide for its many activities. The Australian legislation is chosen because of the unusual structure of its regulatory regime. In other words, its legislation is selected because of its very detailed and explicit provisions, especially on the issue of liability and damages. Furthermore its legislation is selected because, although similar to the UK in having a single legal framework, Australia also has a set of regulations that spell out the provisions of the legislation. Those materials are also in a language that makes them easily accessible to the researcher. Japan is chosen due to its geographical location (Asia) and its legal framework is selected because, although Japan has embarked in many space-related activities and has much modern technology in its space equipment, its legislation is very simple and mainly focuses on the formation of the agency that oversees outer space activities in Japan.

\section{Methodology of Research}

The methodology used for this research is a comparative analytical approach where information is gathered through reading and analysing written material which includes international treaties and resolutions, national legislations, case law, books, journals, outcomes of symposiums, conferences, colloquiums, governmental publications and reports from newspapers and internet sources.

The approach of this research is to give primacy to international law and to use relevant literature and the experience of the case study states to illustrate how international obligations are implemented. Hence, this research analysed the relevant international treaties that are applicable. Whilst giving international law paramount consideration, the researcher also looked at international law through the analytical framework derived from the work of commentators. This is because these commentaries may be regarded as valuable indicators of how any rules of international law might be applied to space activity and also whether analogies with other bodies of law, such as liability for other kinds of hazardous activity, might be fruitful. As such, due reference was made to the recommendations that have been made by experts in space law regarding the provisions that should be incorporated into a legal framework. The four case study states, which were used as illustrations and explanations of how international law requirements may be implemented, were based first on a comparison with the analytical framework developed from states' international obligations and from the literature review. Thus the conclusion from those case studies lead to an ideal refined set of legal framework where recommendations as to the key components of an effective outer space legislation can be developed. As such, in order to develop the ideal refined framework, a clear analysis of the similarities and differences between the four case studies were made.

At this juncture we can see that whilst the approach of this research is to give primacy to international law, relevant literature and the legislation of case study states were considered. This is because, 
although international law is valuable for proposing and testing elements of an appropriate law, nevertheless it is not sufficient in itself. This is because of three reasons. Firstly, few signatories suggests that most of the treaties are not very influential or not perceived as suitable; secondly, most of the treaties are written at a high level of generality, leaving wide scope for implementation, whereby a test of 'not inconsistent' could be used rather than a test of positive consistency, and thirdly, the work of commentators suggests that the treaties concluded so far may not deal with all desirable elements. As such, understanding of international law were supplemented by an analytical framework drawn from the work of commentators analysed by way of literature review and the results were used to structure subsequent arguments according to the elements identified as desirable.

In summary, states wishing to be active in Outer Space must meet relevant international obligations if their right to be active is not to be challenged. Integral to these obligations is the need to have a regulatory regime that meets certain requirements laid down by international law. How these obligations may be met is explained more fully in relevant literature and is illustrated by reference to existing legal regulation of outer space activities in various states. Therefore, this research will set out a clear analytical framework based on a thorough analysis of international obligations and relevant literature, and use that as a basis for analysing the legislation of the case study states. The case studies will then be used to highlight what legislation that meets the requirements of the analytical framework would look like in practice and where adjustments might be necessary to the analytical framework.

\section{An Ideal Legal Framework}

The question that needs to be answered is, what is an ideal shape of a regulatory framework for spacerelated activities for countries such as Malaysia, which are rapidly developing economically, regard space activities as an important aspect of economic development, and have an ambitious and expanding space programme? The answer to this would be, an ideal shape of a legislative framework is a legislative framework that has these three attributes. Firstly, it should conform to the key obligations and requirements under international law as prescribed by the international treaties of outer space, secondly, whilst conforming to the obligations and requirements under international law as prescribed by the international treaties of outer space, a legal framework should also contains all provisions and characteristics that have been identified by space law experts as compulsory and desirable, and thirdly, whilst conforming to the obligations and requirements under international law as prescribed by the international treaties of outer space, it should also be compatible with the economic status of Malaysia as a developing country, hence containing all the best features of the legal framework of developed states which are active in space-related activities combined. This is because, as a developing common law country that aspires to become a developed country by the year 2020, Malaysia seeks to model its laws on the laws adopted by developed states which are active participants in space-related activities. As such, based on these three attributes, states wishing to be active in outer space must meet pertinent international obligations if their right to be active is not to be challenged. Integral to these obligations is the need to have a regulatory regime that meets the requirements laid down by international law.

How these obligations may be met is explained by reference to existing legal regulation of outer space activities in selected states. In other words, Malaysia can learn from the experience of other states already more established in space activities and with different methods of applying national laws within the context of international law.

\section{Compulsory Provisions of an Outer Space National Legal Framework}

Based on the provisions under outer space treaties, literature reviews, similarities and differences, strengths and weaknesses of the national space legislation of the UK, USA, Australia and Japan, the key components or elements and the best features and design of an effective outer space legislation for space activities has been identified. Thus, an ideal legal framework for Malaysia and other similar states should contain the followings:

1. A legal framework that contains all four key provisions that reflect the key obligations that states must fulfil under international space law and compulsory provisions that are recommended by experts in space law.

a. Provisions that allow states to authorise and supervise space activities that those under states' jurisdiction wish to undertake and to continue supervising the space activities that have been undertaken until they end (Authorisation and Supervision).

b. Provisions that require states' entities to be responsible towards the consequences of their activities (Responsibility and Liability). 
c. Provisions that require states to their register space objects within their national registry (Registration of Space Objects).

d. Provisions that encourage international cooperation when states entities participate in space-related activities (International Cooperation).

2. The best features for the provisions on Authorisation and Supervision are:

a. Provisions that clearly lay down the procedure that needs to be followed by the applicant of a licence when he wants to undertake space activities and the procedure that needs to be followed by the Minister involved when dealing with the application submitted to him for approval - similar to the provision adopted by the USA's United States Code, Title 15, Chapter 82 on Land Remote Sensing Policy and the United States Code, Title 49, Chapter 701 on Commercial Space Launch Activities.

b. Provisions that allow Minister involved to issue any documentation or guidelines for the purpose of clearly highlighting and elaborating states' key obligations under international law - similar to provisions adopted by the UK's Outer Space Act 1986.

c. Provisions providing for exceptions to the requirement of an authorisation - similar to the provision adopted by the UK's Outer Space Act 1986 and the United States Code, Title 49, Chapter 701 on Commercial Space Launch Activities.

d. Provisions that require the consent of a licensee before the licence is revoked similar to the provision adopted by the UK's Outer Space Act 1986.

e. Provisions that allow for parties to appeal when they are not satisfied with the outcome of the authorisation and supervision - similar to the provision adopted by similar the USA's United States Code, Title 15, Chapter 82 on Land Remote Sensing Policy and the United States Code, Title 49, Chapter 701 on Commercial Space Launch Activities and the Australia Space Activities Act 1998.

3. The best features for the provisions on Responsibility and Liability are:

a. Provisions on insurance and identifying the amount of insurance needed - similar to the provision adopted by similar to the provision adopted by the USA's United States Code, Title 49, Chapter 701 on Commercial Space
Launch Activities and the Australian Space Activities Act 1998.

b. Provisions that indemnify the government for action taken against it - similar to the provision adopted by the UK's Outer Space Act 1986 and Australia Space Activities Act 1998.

c. Provisions that clearly specify or identify the types of action or omission that amount to breach of national space legislation as criminal offence and state a fixed monetary amount or equivalent as regards to the punishment imposed under criminal offences similar to the provision adopted by the Australian Space Activities Act 1998.

d. Provisions that clearly specify or identify the types of action or omission that amount to breach of the national space legislation leading to civil penalty and state a fixed monetary amount or equivalent as regards to the punishment imposed under civil penalties - similar to the provision adopted by the United States Code, Title 15, Chapter 82 on Land Remote Sensing Policy, the United States Code, Title 49, Chapter 701 on Commercial Space Launch Activities and the Australian Space Activities Act 1998.

4. The best features for the provisions on Registration of Space Objects are:

a. Provisions that specifically lay down the information that is required for registering space objects - similar to the provision adopted by the Australian Space Activities Act 1998.

b. Provisions that also allow any person to inspect the Register - similar to the provision adopted by the UK's Outer Space Act 1986 and the Australian Space Activities Act 1998.

1. The best features for the provisions on International Cooperation.

Due to the fact that none of the national space laws of the case study states contain provisions that encourage or promote international cooperation, I propose that the best feature would be a provision that:

a. Clearly state that states are required to encourage participants of space-related activities to forge international cooperation when they participate in space-related activities.

6. The best desirable characteristics of national space legislation are: 
a. National space legislation that is comprehensive in regulating space activities that is intended for - similar to the provision adopted by the UK's Outer Space Act 1986 and the Australia Space Activities Act 1998.

b. National space legislation that clearly identifies space policy objectives which conform to international obligations - similar to the provision adopted by the National Aeronautics and Space Act 1958.

c. National space legislation that provides a straightforward licensing regime - similar to the provision adopted by the UK's Outer Space Act 1986.

\section{Recommendations}

It is recommended that Malaysia should expedite the drafting and adoption process of its Draft Malaysian Outer Space Act so as to provide for the regulation of its space-related activities. It is crucial for Malaysia to have enforced national space legislation because the existence of national space legislation will indicate that it conforms to the requirements placed upon it under international space law. A practical reason is that since Malaysia is an active player in the arena of outer space activities, national space legislation will ensure transparency of the rules and regulations pertaining to its space-related activities. When the procedure and rules are clear it will assist in the efficiency of conducting its space-related activities; otherwise it will create inconsistency among those who want to participate in them. Moreover, national space legislation is also necessary as it can clearly identify the administering body that is in charge of administering the space-related activities as well as clearly providing for criminal liabilities and civil penalties for compensation purposes ${ }^{22}$. As such, the initiative of the Attorney General's Chambers to finalise the Draft Malaysian Outer Space Act to regulate the space activities is very much awaited.

22 As one commentator has observed, 'since the international space conventions only deal with the rights and obligations of states, national space legislation offers states the opportunity to regulate internally the relationship between the State and private enterprise involved in space activities and proportionate liabilities between them'. In Hanneke L. V. T. E., 'Commercialization of space activities, legal requirements constituting a basic incentive for private enterprise involvement', (1996) 12 (2) Space Policy 119.
1. It is recommended that Malaysia should expedite the process of developing its space policy, so that it can be explicitly incorporated into the Draft Malaysian Outer Space Act thus conforming to the best characteristic of national space legislation that requires national space legislation to clearly identify its space policy objectives which conform to international obligations.

2. Except for the principles contained in the 1967 Outer Space Treaty that are binding upon Malaysia due to the treaty's status as customary international law, Malaysia has not ratified the remaining, more specific, UN outer space treaties. As such, it is recommended that Malaysia ratify those treaties. Although it may seem that it would be better for Malaysia not to ratify the treaties which would mean that Malaysia would have fewer obligations, if we examine the intention of the 1967 Outer Space Treaty through its Preamble, we can appreciate that one of the reasons why the 1967 Outer Space Treaty was introduced was, and still is, to ensure that all states participating in space-related activities can do so in a peaceful and systematic environment. Due to this intention, since Malaysia is already bound by the principles of the 1967 Outer Space Treaty, through international customary law, Malaysia should be encouraged to seriously consider the need to ratify them and become bound by their exact procedures and systems. This is because, although the 1967 Outer Space Treaty contains the basic provisions, the four remaining treaties clearly give systematic and clear procedures of how a State should act or react in any given situation. If Malaysia is still reluctant to ratify these treaties, in my opinion, Malaysia should at least ratify the Agreement on Rescue of Astronauts, the Return of Astronauts and of Objects Launched into Outer Space $1968^{23}$. This is due to the fact that, since Malaysia has the activity of sending astronauts to outer space, it would be as an advantage for Malaysia and its astronauts because, although the 1967 Outer Space Treaty has already stated that states must protect the interest of all astronauts

23672 UNTS 119, adopted by the General Assembly in its resolution 2345 (XXII) on 19 December 1967, opened for signature on 22 April 1968, entered into force on 3 December 1968. 
irrespective of their nationalities ${ }^{24}$, the 1968 Rescue agreement clearly and articulately provides for the procedure that needs to be followed in the event that a Malaysian astronaut were to face misfortune.

3. It is recommended that Malaysia should consider the approach taken by the UK in further elaborating on the provisions of its Outer Space Act 1986 by having explanatory documents. These documents in the UK are the 'Information for Applications for a Licence', and the 'Application for Licence Notes to Help you Complete the Form'. While the first document contains information that the licensee needs to know before making the application, the second document assists the applicant in applying for the licence. In my opinion, similar guidance would be necessary to complement the Draft Malaysian Outer Space Act. For example, the UK's document entitled 'Outer Space Act 1986 -Information for Applications for a Licence' provides for the exact amount of insurance that the applicant of the licence is required to have if he wants to undertake any space-related activity that is authorised by Outer Space Act 1986. By having this document, it serves as clear legal information on the value of how much insurance cover the applicant needs to have. Therefore, if, for example, an applicant does not have the required amount of insurance, the Secretary of State may refuse his application on that ground. Secondly, as a practical reason, similar to the approach taken by the UK, these two documents would also serve to enable applications for a licence to be made easily thereby saving time. In my opinion, without these documents, time might be lost unnecessarily by making mistakes in filling the form and refilling it and having the officers of the Malaysian Space Centre answer questions when it concerns a straightforward answer. Thus, these documents would make the application procedure more transparent hence avoiding potential delays in the application procedure and making it more efficient for the licensing authority. Furthermore, these documents would be important and necessary because if all the information were to be incorporated into the Draft Malaysian Outer Space Act 2005 it would be very bulky. Additionally, in

${ }^{24} 1967$ Outer Space Treaty, Article V. a situation where information in the documents needed to be changed, for example the amount of the fee, it could easily be amended. On the other hand, if the fee were to be incorporated into the Malaysian Outer Space Act 2005 and later needs to be changed, the Malaysian Outer Space Act 2005 would have to go through a lengthy process of amendment.

4. It is recommended that Malaysia should also consider the approach taken by the USA in proposing for the codification of all USA's legislation pertaining to its space-related activities. With this approach, all legislation pertaining to matters relevant to its spacerelated activities would be compiled in one Title. The advantage of taking this approach is, apart from its transparency, that it could avoid wastage of time in court proceedings. This can be seen when a proceeding in court is delayed on technical or procedural issues rather than the actual dispute on the matters itself due to a mistake made by overlooking relevant legislation pertaining to the dispute.

5. Similar to the provisions in the United Kingdom's Outer Space Act 1986, it is also recommended that the Malaysian government continues supporting activities relating to the space programme provided that the national security of Malaysia would not be threatened, public health and safety of her nationals and international population at large would not be jeopardised, and the activity is consistent with the international obligations of Malaysia. Even if the provisions are not incorporated explicitly into Malaysian law, it should be made as the aspirations of the Malaysian Government. To this effect, if a space activity falls under the above criteria, the Malaysian Government should therefore support the activity irrespective of the differences in political opinion or ideology of parties in Malaysia.

6. It is recommended that Malaysia should consider the approach taken by the UK's Outer Space Act 1986 and the United States Code, Title 49, Chapter 701 on Commercial Space Launch Activities in incorporating provisions for the exceptions to the requirement of an authorisation in the Draft Malaysian Outer Space Act . Malaysia could include provisions to the effect that, after protecting Malaysia's national security and 
Malaysia's key international obligations, certain situations do not require authorisation. By having this provision in the Draft Act, it would allow Malaysia to act consistently with its international obligations, in the sense that the authorisation body may never be allowed to refuse any activity if the activity would result in Malaysia securing compliance with its international obligations in respect of its space-related activities.

7. It is recommended that Malaysia should consider the approach taken by the Australian Space Activities Act 1998 in incorporating provisions that clearly specify or identify the types of action or omission that amount to a breach of national space legislation as a criminal offence in the Draft Malaysian Outer Space Act . Malaysia could include provisions that clearly specify or identify the types of action or omission that would amount to the breach of national space legislation and constitute a criminal offence. By having this provision in the Draft Act, it would allow all parties to know clearly which act or omission would amount to a breach of their obligations.

8. It is recommended that Malaysia should consider the approach taken by the United States Code, Title 15, Chapter 82 on Land Remote Sensing Policy, the United States Code, Title 49, Chapter 701 on Commercial Space Launch Activities and the Australian Space Activities Act 1998 in incorporating provisions that clearly specify or identify the types of action or omission that amount to the breach of national space legislation under civil penalty, and provisions that state a fixed monetary amount or equivalent as regards to the punishment imposed under civil penalties in the Draft Malaysian Outer Space Act . Malaysia could include provisions that clearly specify or identify the types of action or omission that would amount to the breach of the national space legislation leading to civil penalty and a fixed monetary amount or equivalent as regards the punishment imposed under civil penalties. By having clear provisions in the Draft Act, it would allow all parties to know which act or omission would amount to a breach of their civil obligations, and by having fixed punishment in the Draft Act, it would avoid any favouritism that would lead to the abuse of discretionary power on the part of the decision maker while giving out his decision.
9. Although it was not recommended by the experts in space law, another recommendation of this research is that national space legislation should have a provision for international cooperation for the reason which is that states should conform to their key obligations under international space law. Although the aim and result of this research is focused primarily for the benefit of Malaysia and other states with similar economic status and level of activity in space, this recommendation in particular should also be adopted by other states which are active in space and which are developing national space legislation to show that they are conforming to the key obligations imposed by the principles of the 1967 Outer Space Treaty.

10. The Malaysian government should consider the Draft Malaysian Outer Space Act with a view to ensuring proper implementation of the powers available to it. This is because having legislation is one thing while implementing it is another. There is no point in having legislation if it cannot be properly implemented. Thus, in order for any spacerelated activities to be effectively conducted, it is recommended that the Malaysian Space Agency and the Malaysian Space Centre be fully effective in order to oversee that the activities are conducted as prescribed or intended by the Government of Malaysia. Thus, Malaysia should ensure that it is equipped with suitable manpower and human resources who are knowledgeable in the area of outer space law. In this regard the government of Malaysia should encourage more nationals to pursue study in this field.

11. The Malaysian government may also wish to consider exploring the possibility of entering into regional arrangements with other ASEAN members in its space-related activities because regional arrangements in the case of the UK and the European Space Agency have proven to be advantageous and beneficial. Therefore, it is recommended that the Malaysian government consider promoting regional arrangements with its neighbours on matters related to outer space activities ${ }^{25}$. This would also conform to Malaysia's international

25 This recommendation supports the view made earlier by Noichim. See Noichim, C., 'Promoting ASEAN space cooperation', (2008) 24 (1) Space Policy 10. 
obligation to cooperate in international activities found in the principles of the 1967 Outer Space Treaty.

It is hoped that Malaysia would benefit from these recommendations to develop the best management of its space-related activities and thus turn its dream 'to provide the legal and administrative infrastructure that will optimise the exploitation of benefits derived from space activities ${ }^{26}$ into reality. Similarly, it is also hoped that other states that have a similar economic background to Malaysia and which are active or want to be active in space would equally benefit from these recommendations. As this research has been able to identify an ideal legal framework not only for Malaysia but also for these other states, these recommendations can thus now be used as an example for both Malaysia and those states as to how to develop an affective outer space regulatory framework which best implements the provisions of international law.

${ }^{26}$ Othman, M. (Datuk Professor Dr), 'The National Space Programme of Malaysia National Space Agency', Proceedings of the United Nations' Workshop entitled 'United Nations Treaties on Outer Space: Actions at the National Level', held at Daejeon, Republic of Korea, 3-6 November 2003, p 73. This statement was made when she was the Director General to the Malaysia National Space Agency. She is presently the Director to the United Nations Office of Outer Space Affairs, Austria. 